\title{
Emerging Markets And Ipos Hooking Up On The Global Horizon
}

\author{
Rahul Bishnoi, (E-mail: finrkb@hofstra.edu), Hofstra University
}

\begin{abstract}
An analysis of the difficult past year shows that emerging markets have actually held their value more successfully than developed markets, with declines of considerably smaller magnitude than those seen in the U.S., Europe and developed Asia. The focus of this paper is on the emerging markets of Latin America and Asia where funds are up more than 50 percent this year after returning nearly 40 percent in 2004 and more than 60 percent in the previous year. After years of doldrums triggered by Brazil's devaluation of the real and the subsequent Argentine crisis, capital markets are regaining strength. In Chile and Brazil, for instance, mergers and acquisitions are on the rise and stock offerings are back in fashion. Even retail investors have joined institutional investors in participating in Initial Public Offerings (IPOs), such as the one from Chile's secondlargest department store, Bipley. Pension funds also have been important to financing, particularly for Chile's biggest companies, though the private pension funds are near their legal limit for equity investments. The first section of the paper focuses on a general definition and characteristics of the global emerging markets. The second section of the paper concentrates on the Latin American Equity and Bond market with special attention towards the performance of the markets over the past year. The final section looks at the recent developments of the region, risks of the region and concludes with suggested policies for the future.
\end{abstract}

\section{WHAT IS AN EMERGING MARKET ECONOMY (EME)?}

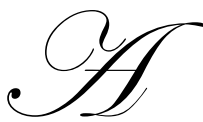

world's economies.

term coined in 1981 by Antoine W. van Agtmael of the World Bank, an emerging, or developing, market economy (EME) is defined as an economy with low-to-middle per capita income. Such countries constitute approximately $80 \%$ of the global population, representing about $20 \%$ of the

EMEs are characterized as transitional, meaning they are in the process of moving from a closed to an open market economy while building accountability within the system. Examples include the former Soviet Union and Eastern bloc countries. As an emerging market, a country is embarking on an economic reform program that will lead it to stronger and more responsible economic performance levels, as well as transparency and efficiency in the capital market. An EME will also reform its exchange rate system because a stable local currency builds confidence in an economy, especially when foreigners are considering investing. Exchange rate reforms also reduce the desire for local investors to send their capital abroad, leading to what is commonly known as capital flight. However, the bigger the risk, so would be the expected reward, so emerging market investments have become a standard practice among investors aiming to diversify while adding risk.

\section{LATIN AMERICA'S EQUITY MARKETS}

Stock markets are soaring in Colombia, Mexico, Chile and Peru. Several of Latin America's chief export commodities have hit record highs, a windfall to producing countries such as Venezuela and Peru. Argentina and Brazil have shaken off the recession of years ago and are seeing brisk growth. Corporations are beginning to rake in fresh capital. After years of doldrums triggered by Brazil's devaluation of the real and the subsequent Argentine crisis, capital markets are regaining strength. In Chile and Brazil, for instance, mergers and acquisitions are on the rise and stock offerings are back in fashion. Even retail investors have joined institutional investors in participating 
in new stock offerings, such as the one from Chile's second-largest department store, Bipley. Pension funds also have been important to financing, particularly for Chile's biggest companies, though private funds are near their legal limit for equity investments.

Mexico, meanwhile, has become a regional darling in corporate finance, in part due to the swarm of foreign financial giants that flocked to the country in recent years and propped up local banks. They now control up to $80 \%$ of the market. The foreign banks cleaned up their balance sheets and injected a lot of capital into the Mexican banks, so during the last two or three years there has been a boom in credit and there is a lot of liquidity in the market. Not surprisingly, Mexico's stock market has skyrocketed, while the peso has appreciated 5\% in 2005 through early August. Meanwhile, country risk fell to a five-year low. Part of what is fueling market liquidity too are the remittances of $\$ 16$ billion annually sent by families overseas to Mexico, which now represents the country's second leading source of income after petroleum. Brazil has become more attractive for corporate finance, with economic output climbing 5\% in 2004. In a 12 month period, Brazil's exports hit a record $\$ 107$ billion and Brazilian workers living abroad sent home $\$ 5.6$ billion in 2004, fueling consumption, growth and investment.

No outlook is flawless however, and the final section of the paper presents several reasons and issues that could roil even the healthiest of economies and undermine their corporate finance. All the major stock indices rose by double-digits during 2004 except for Colombia, which shot up more than 116\%.

\section{LATIN AMERICA'S BOND MARKET}

The emerging market tradable debt universe continues to expand reaching US\$3.1 trillion in 2003. The regional breakdown of the debt universe shows Latin America losing some of its dominant share of the total debt outstanding. More debt is now represented by each of the other three regions, which indicates more global diversification in debt stock, Latin America now represents $48 \%$ of the external debt outstanding, down from $60 \%$ in 1995. High sovereign refinancing needs have resulted in higher levels of new issuance corporate, borrowers continue to gain access to the international capital markets.

\section{Regional Breakdown of External Debt Universe.} (\% of Total)

\begin{tabular}{|c|c|c|c|c|c|}
\hline Region & $\mathbf{1 9 9 5}$ & $\mathbf{1 9 9 7}$ & $\mathbf{1 9 9 9}$ & $\mathbf{2 0 0 1}$ & $\mathbf{2 0 0 3}$ \\
\hline Latin America & $60 \%$ & $49 \%$ & $52 \%$ & $53 \%$ & $48 \%$ \\
\hline Asia & $22 \%$ & $27 \%$ & $25 \%$ & $23 \%$ & $25 \%$ \\
\hline Emerging Europe & $13 \%$ & $21 \%$ & $19 \%$ & $18 \%$ & $20 \%$ \\
\hline Middle East/Africa & $5 \%$ & $3 \%$ & $5 \%$ & $6 \%$ & $7 \%$ \\
\hline
\end{tabular}

Source: Merrill Lynch, BIS

The overall stock of Mexican Peso denominated public debt closed 2003 at approximately $\$ 85$ billion. The main driver behind the growth of the stock of debt continues to be the federal government, which has financed its deficit exclusively in the domestic market since 1996. Mexico's funding program seeks to continue to reduce currency risk through lowering of external debt and thus, interest rate risk.

Chilean-Peso debt has become a very important source of funding for the corporate sector in Chile. With the improvement in the credit rating of the Chilean economy, the government has been looking to use CLPdenominated instruments to raise funds domestically and abroad. Most of the CLP debt is issued by the Central Bank for monetary policy objectives. This instrument can be expected to keep on growing as the domestic financial market deepens. 


\section{RECENT DEVELOPMENTS IN THE REGION}

1. In the Latin American region, growth is moderating after reaching a 24-year high in 2004. Nonetheless, projected growth rates of about 4 percent in 2005 and 33/4 percent in 2006 are still well above historical averages. Recent growth performance has been supported by the continued strength of global commodity and raw material prices that have boosted terms of trade and receipts from exports. Mexico and some countries in South America have gained, in particular, from the surge in fuel, food, and metals prices, and have generally been able to exploit these opportunities by expanding volumes-in some cases very substantially.

2. A strengthening of policies and improved confidence have been reflected in exchange rate appreciations since mid-2004. For six large countries in the region (Argentina, Brazil, Chile, Colombia, Mexico, and Peru), the nominal effective rate rose by an average of about 9 percent since the beginning of 2005 (based on data through end-July), with a larger increase in Brazil (24 percent), without significantly affecting exports. At the same time, reserves have continued to rise; for example, in Argentina, they are approaching US\$26 billion.

3. The increasing role of domestic currency financing in the region also represents a source of resilience. A number of countries-most notably Brazil, Chile, Colombia, Mexico, and Peru-have increased their reliance on domestic debt issuance, reducing their vulnerability to exchange rate risk and increasing the liquidity of local currency markets. Some countries, including Brazil, Colombia and Uruguay, have also issued global bonds in local currency e.g. Brazil recently issued its first global bond denominated in Brazilian-Real on September $23^{\text {rd }} 2005$ worth approximately US $\$ 300$ million. The increased use of domestic debt instruments at longer maturities-most prominently in Colombia, Chile, Mexico, and Peru-has also helped improve debt profiles. In some cases, foreign investors have shown strong interest in domestic bond issues (in Mexico, some of the issues at the long end of the curve, at times, have been taken up almost entirely by foreign investors).

\section{RISKS FOR THE REGION}

1. A sharper-than-expected slowdown in key trading partners or international trade. Despite the success in recent years in diversifying exports, the U.S. market accounted for over 40 percent of the increase in the Latin American region's exports between 2002 and 2004. For the region as a whole, the risks related to a slowdown in growth in China appear to be low, given its modest share of exports.

2. Higher world oil prices and/or a weakening of global commodities markets. Recent increases in oil prices are not expected to affect the region's growth prospects as a whole, but only for some smaller net oilimporting countries.

3. Widening risk spreads for emerging market countries would also adversely affect fiscal and external positions in many countries in the Latin American region. The region has benefited significantly from the unusually low level of global interest rates, which has encouraged a "search for yield" and bid down spreads on emerging market debt.

4. The fourth and final risk relates to the political context. In the next 18 months, 19 countries in the region, including the largest Latin American countries, are slated to have elections, the results of which will affect more than 520 million people. These elections provide an important opportunity to secure mandates for renewed structural reforms and fiscal sustainability efforts. The return of the region to broad macroeconomic stability should facilitate the transitions, and underpin the efforts being made to secure policy continuity and structural change. 


\section{POLICIES FOR THE FUTURE}

1. First, continued institutional and policy reforms to reduce public debt. Buoyant economic activity and the fiscal consolidation efforts of recent years have helped bring debt ratios down significantly throughout the Latin American region. Nevertheless, debt ratios continue to exceed the average of the mid-1990s, and generally remain above levels generally viewed as conducive to growth and broader macroeconomic stability. For oil exporters such as Ecuador, Mexico, and Venezuela, today's high prices provide an exceptional opportunity to further reduce public debt.

2. A second policy challenge is to maintain low inflation. Notwithstanding the remarkable progress in reducing inflation in the region, there remains scope to further entrench these gains. For example, sustaining the credibility of inflation-targeting frameworks, which have helped to anchor inflation expectations in a number of large Latin American countries, will be important in containing inflationary pressures. Further steps to enhance central bank independence and policy transparency would be helpful in this regard.

3. Financial sector reforms need to be accelerated. Latin America still lags behind other regions in financial intermediation and credit availability. Countries in the region will need to continue to give priority to strengthening financial system regulation, building consolidated supervision, bringing financial institutions up to international prudential standards, and upgrading bankruptcy laws. The continued development of local currency capital markets (including the deepening of local government and corporate bond markets, equity markets, and the introduction of derivative products, where appropriate) to manage interest rate and exchange rate risk would also help improve the efficiency of financial intermediation.

4. Greater trade openness and foreign direct investment need to be fostered. Notwithstanding recent gains, Latin America is still relatively closed to international trade compared with other dynamic regions. Key areas of particular importance to the region include the phasing out export subsidies and market access for agricultural imports; tariff reductions on other goods by middle-income countries; and the treatment of services.

5. Efficiently managing and using natural resources: Despite having the largest proven oil reserves in the world after the Middle East, the region has been unable to increase production to take full advantage of the boom in oil prices.

6. More generally, business climates need to be improved to encourage private investment, particularly by strengthening the rule of law and the enforcement of contracts, improving regulatory frameworks, and by strengthening competition policy. Governance also needs to be improved.

\section{REFERENCES}

1. Molinsky, Michael, Latin America: Best Stocks, Best Funds, Bloomberg Press, Annual issues .

2. Size and Structure of the World Bond Market: 2005. Merrill Lynch, Global Fixed Income Research Team. 